\title{
THE SIGNIFICANCE OF MULTIDISCIPLINARY APPROACH FOR THE INCREASING IN PATIENTS WITH DIABETES MELLITUS 2 TYPE QUALITY OF LIFE LEVEL
}

\author{
Anna Kohut ${ }^{1}$, M. Bobryk ${ }^{2}$, J. Komisarenko ${ }^{2}$, O. Chaban ${ }^{3}$ \\ ${ }^{1}$ Communal Noncommercial Institution of Kyiv Regional Council "Regional Psychiatric and \\ Narcological Medical Association", Glevakha, Ukraine \\ ${ }^{2}$ Department of Endocrinology of Bogomolets National Medical University, Kyiv, Ukraine \\ ${ }^{3}$ Department of Medical Psychology, Psychosomatic Medicine and Psychotherapy of \\ Bogomolets National Medical University, Kyiv, Ukraine
}

\begin{abstract}
.
Introduction. Diabetes mellitus 2 type has become a global health problem and is by far one of the most common chronic diseases, so there is an urgent need to provide high quality medical and social care to this patient population. It is known that this group of patients is characterized by a number of specific features that distinguish them and create difficulties for physicians in the treatment process.

Purpose. Study has been devoted to the comprehensive assessment of affecting factors on the quality of life of patients with type 2 Diabetes Mellitus (T2DM) in relationship with their psychological status indicators and level of compliance.

Materials and Methods. Study population consisted of T2DM ( $n=40)$ equivalented by the indicators of age, body mass index, blood pressure, laboratory level of blood glucose and glycated hemoglobin (HbA1c). All patients signed a voluntary informed consent before the study. Study data has been collected using informed patients form and 6 validated psychometric scales: Chaban Quality of Life Scale (CQLS), Medication Compliance Scale (MCS), Toronto Alexithymia Scale (TAS-20), Dysfunctional Attitudes Scale (DAS), Depression, Anxiety and Stress Scale (DASS-21)) and Holmes and Rahe Stress Scale (HRSS). Glycemic control has been based on HbA1c results and blood glucose level.

Results. Statistically significant difference has been found between the groups of the patients with high, middle and low level of their commitment to therapy according to MCS results. A significant correlation has been found between the following indicators: HbA1c and body mass index of patients with T2DM $(\mathrm{p}=.19 ; \mathrm{r}=.368)$ and presence of alexithymia $(\mathrm{p}=.039 ; \mathrm{r}=-.328)$. Depending on the level of quality of life with numeral scores of results with other scales: MCS ( $\mathrm{p}=.361 ; \mathrm{r}=.022)$; DAS ( $\mathrm{p}=.027 ; \mathrm{r}=-.350)$, stress level (DASS 21) $(\mathrm{p}=.038 ; \mathrm{r}=-.339)$, depression (DASS -21$)(\mathrm{p}=.002 ; \mathrm{r}=-. .471)$ and HRSS $(\mathrm{p}=.006 ; \mathrm{r}=-.425)$.
\end{abstract}


Conclusion: Psychological indicators identified by results of research such as, level of: compliance, cognitive distortions, depression, stress resistance and social adaptation - affected quality of life of T2DM patients, as well as indicators of alexithymia, anxiety, and quality of life affected the level of their commitment to treatment. Patients with low level of compliance and quality of life had the increased risk of treatment non-efficiency as a result. Therefore, multidisciplinary approach in the treatment of each individual patient, would potentially improving the adherence and effectiveness of T2DM treatment.

Keywords: diabetes mellitus 2 type, health, healthcare, mental health, mental illness, stress, quality of life, social welfare

\section{The authors declare that they have no competing interests}

\section{References}

Mogre, V., Johnson, N., Tzelepis, F., Shaw, J., \& Paul, C. (2017). Adherence to self-care behaviours and associated barriers in type 2 diabetes patients of low-and middle-income countries: a systematic review protocol. Syst Rev. 2017 Feb 27;6(1):39. doi: 10.1186/s13643-017-0436-4.

Indelicato, L., Dauriz, M., Santi, L., Bonora, F., Negri, C., Cacciatori, V., Targher, G., Trento, M., \& Bonora, E. (2017). Psychological distress, self-efficacy and glycemic control in type 2 diabetes. Metab Cardiovasc Dis. 2017 Apr;27(4):300-306. doi: 10.1016/j.numecd.2017.01.006. Epub 2017 Jan 31.

Esmaeilinasab, M., Ebrahimi, M., Mokarrar, MH., Rahmati, L., Mahjouri, MY., Arzaghi, SM. (2016). Type II diabetes and personality; a study to explore other psychosomatic aspects of diabetes. J Diabetes Metab Disord. 3;15:54 doi: 10.1186/s40200-016-0281-3

Shamsi, F., Khodaifar, F., Arzaghi, SM., Sarvghadi, F, Ghazi, A. (2014). Is there any relationship between medication compliance and affective temperaments in patients with type 2 diabetes? (2014). J Diabetes Metab Disord. 27;13(1):96. doi: 10.1186/s40200-014-0096-Z

Conti, C., Di Francesco, G., Fontanella, L., Carrozzino, D., Patierno, C., Vitacolonna, E., \& Fulcheri, M. (2017). Negative Affectivity Predicts Lower Quality of Life and Metabolic Control in Type 2 Diabetes Patients: A Structural Equation Modeling Approach. Front Psychol. 24;8:831. doi: 10.3389/fpsyg.2017.00831

Kohut, A., Potapov, O., Frankova, I., Bobryk, M., Komisarenko, J., \& Chaban, O. (2019). Multidisciplinary Intention: Revealing The Consequence of Psychosocial Factors on the Adherence to Treatment of the Patients with Type 2 Diabetes Mellitus. Mental Health: Global Challenges Journal, 2(1), 15-17. https://doi.org/10.32437/mhgcj.v2i1.43

Chaban, O., Khaustova, O., \& Bezsheiko, V. (n.d.). Reliability and validity of Chaban Quality of Life Scale. Retrieved from https://www.ecnp.eu/presentationpdfs/70/P.2.h.301.pdf 


\title{
ЗНАЧЕННЯ МІЖДИСЦИПЛІНАРНОГО ПІДХОДУ ДЛЯ ПІДВИЩЕННЯ РІВНЯ ЯКОСТІ ЖИТТЯ ПАЦІЕНТВ ІЗ ЦУКРОВИМ ДІАБЕТОМ 2 ТИПУ
}

\author{
Анна Когут $^{1}$, М. Бобрик ${ }^{2}$ Ю. Комісаренко ${ }^{2}$, О. Чабан ${ }^{3}$ \\ 1. Комунальний некомерційний заклад Київської обласної Ради "Обласне \\ психіатрично-наркологічне медичне об'єднання "
}

2. Кафедра ендокринології НМУ ім. О. О. Богомольця

3. Кафедра медичної психології, психосоматичної медицини і психотерапії НМУ ім. О. О. Богомольця

Вступ. Цукровий діабет 2 типу (ЦД2) став глобальною світовою проблемою охорони здоров'я і на сьогоднішній день - $є$ одним із найбільш поширених хронічних захворювань тому існує нагальна потреба у наданні високоякісної медичної та соціальної допомоги даному контингенту пацієнтів. Згідно зі зростанням показників захворюваності та поширеності на ЦД2 в динаміці наразі та у перспективі, серед населення у світі - $€$ потреба в покращенні процесу та результатів лікування ЦД2 та його ускладнень (Mogre, Johnson, Tzelepis, Shaw, \& Paul, 2017).

Відомо, що для цієї групи пацієнтів є характерними низка специфічних ознак, що вирізняють їх і створюють певні труднощі для лікарів у процесі лікування. Так, наприклад, було встановлено взаємозв'язок між глікемічним профілем, психосоматичними аспектами та комплаєнсом до лікування . Деякі специфічні для пацієнтів з ЦД2 психологічні характеристики можуть безпосередньо бути корисними для оцінки впливу психосоціальних факторів на контроль рівня глікемії для досягнення встановлених глікемічних цілей (Indelicato et al., 2017).

Однією із проблем у пошуку шляхів покращення результатів лікування пацієнтів з ЦД2 є чітке розуміння рівня їх комплаєнтності та факторів, як індивідуальних, так і та зовнішніх, які впливають на це (Esmaeilinasab et al., 
2016). Контроль рівня глікемії багато в чому залежить від дотримання встановленої схеми медикаментозної терапії (Shamsi, Khodaifar, Arzaghi, Sarvghadi, Ghazi, 2014) .

Останні тенденції підтверджують думку про те, що міждисциплінарний підхід із залучення фахівців із різних сфер охорони здоров'я 3 метою прийняття колегіальної тактики лікування кожного окремого пацієнта може потенційно вплинути на покращення показників прихильності та ефективності лікування пацієнтів з ЦД2 (Conti et al., 2017).

Мета. Дослідження було присвячено комплексній оцінці впливу факторів на якість життя пацієнтів з ЦД2 у залежності від показників їхнього психологічного статусу та рівня комплаєнтності.

Матеріали і методи. Дослідження було проведене на базі Київського Міського Клінічного Ендокринологічного Центру на базі кафедри ендокринології у співпраці 3 кафедрою медичної психології, психосоматичної медицини та психотерапії Національного медичного університету імені О. О.Богомольця. Популяція дослідження (n = 40) складається 3 пацієнтів з ЦД2 (чоловіки - 32, 5\%, жінки - 67, 5\%). 3а сімейним станом: одружених - 60\%. За рівнем освіти: мали вищу закінчену освіту - 60\% пацієнтів з ЦД2. Також мали різний рівень ожиріння - 50\% 3 даної вибірки пацієнтів. Було проведено аналіз даних первинної документації - медичних карт стаціонарного хворого. Представники даної статистичної вибірки були еквівалентними за такими показниками: віком, індексом маси тіла, рівнем артеріального тиску, лабораторними показниками крові - глюкози та глікованого гемоглобіну (HbAlc) (Kohut et al., 2019). Дані для дослідження, були зібрані із застосуванням інформованої згоди для пацієнтів та 6 валідованих психометричних шкал: медикаментозного комплаєнсу (ШМК), Торонтської шкали алекситимії (TAS-20), стресостійкості та соціальної адаптації Холмса і Раге (HRSS), дисфункціональних відношень (ШДВ), депресії, тривоги і стресу(DASS 21) та оцінки якості життя (ШЯЖ) (Chaban, O., Khaustova, O., \& Bezsheiko, V, (n.d.). Глікемічний контроль оцінювався за результатами останніх лабораторних показників HbA1c та рівня глікемії на момент опитування у пацієнтів з ЦД2. Статистичний аналіз проводився з використанням методів 
описової статистики та кореляції за методом Пірсона за допомогою програмного забезпечення MS Excel та SPSS 23.0.

Результати. Статистично значима різниця була виявлена між групами із високим (30\%), середнім (35\%) та низьким рівнем (35\%) комплаєнтності за числовими результатами ШМК у пацієнтів з ЦД2 (p?). Пацієнти із високими показниками за ШМК мали статистично вищий рівень за числовими показниками шкали оцінки якості життя та протилежні показники за результатами інших шкал (Таб. 1, 2). Було також виявлено значимий кореляційний зв' язок між такими показниками: HbAlc та індексом маси тіла у пацієнтів $(\mathrm{p}=.19 ; \mathrm{r}=.368)$ і наявністю у них алекситимії $(\mathrm{p}=.039 ; \mathrm{r}=$ - .328). В залежності від рівня якості життя за шкалою якості життя у пацієнтів за числовими результатами $з$ іншими шкалами: ШМК ( $\mathrm{p}=.361$; $\mathrm{r}=$ $.022)$; ШДВ ( $\mathrm{p}=.027 ; \mathrm{r}=-.350)$, рівнем стресу (DASS -21$) \quad(\mathrm{p}=.038 ; \mathrm{r}=-$ $.339)$, депресії (DASS - 21) ( $\mathrm{p}=.002 ; \mathrm{r}=$ - .471) i HRSS $(\mathrm{p}=.006 ; \mathrm{r}=-.425)$.

Висновки. Психологічні показники, виявлені за результатами досліджень, такі як: рівень комплаєнтності, когнітивні спотворення, депресія, рівень стресу, стресостійкості та соціальної адаптації - впливають на якість життя у пацієнтів з ЦД2. Також, разом з попередніми, показники рівня алекситимії, тривожності та якості життя — мають вплив на рівень їх прихильності до лікування. Було також виявлено взаємозв'язок між рівнем глікемії та психологічними аспектами у пацієнтів з ЦД2. Пацієнти із низькими рівнями показників комплаєнтності та якості життя мають підвищений ризик до виявлення неефективності лікування у результаті і потребують кваліфікованої допомоги від представників сфери охорони психічного здоров'я у взаємодії із профільними спеціалістами для забезпечення мультидисциплінарного підходу у вирішенні проблем даних пацієнтів. Це широкий обсяг для досліджень, у галузі як медичних, так і соціальних наук. Мультидисциплінарні та мультицентрові дослідження можуть бути перспективними у майбутньому, тому що різні фахівці об'єднуються для вирішення проблеми коморбідності з метою покращення результатів лікування пацієнтів. 